\title{
PERAN PSIKOLOGI PENDIDIKAN AGAMA KRISTEN DALAM PROSES PEMBELAJARAN ANAK USIA DINI DI MASA PANDEMI
}

\author{
Wiwiet Arie Shanty ${ }^{1}$ Talizaro Tafonao ${ }^{2}$ \\ Mahasiswa Program Pascasarjana Magister Pendidikan Agama Kristen Sekolah Tinggi Teologi Real \\ Batam ${ }^{1}$ Dosen Sekolah Tinggi Teologi Real Batam ${ }^{2}$ \\ E-mail: wiwietarieshanty@gmail.com ${ }^{1}$ talizarotafoanao@gmail.com²
}

Diterima tanggal: 11 Juni 2021

Dipublikasikan tanggal: 30 Juni 2021

\begin{abstract}
ABSTRAK
Tujuan penulisan artikel ini adalah melihat sejauh mana peran psikologi Pendidikan Agama Kristen dalam menyiapkan metode pembelajaran kepada anak usia dini di masa pandemi. Hal ini dikarenakan pembelajaran anak usia dini di masa pandemi covid 19 menjadi perhatian dan tantangan tersendiri bagi guru dalam melaksanakan pembelajaran. Selain itu, pendidikan pada anak usia dini memerlukan strategi yang cukup memadai. Itulah sebabnya guru dituntut untuk berupaya memahami berbagai problem yang dihadapi dalam mendidik anak usia dini. Metode penelitian yang digunakan adalah kualitatif dengan mengumpulkan data melalui pengamatan langsung oleh peneliti dan wawancara dengan guru dan orang tua wali murid. Proses analisis yang dilakukan adalah menggunakan berbagai sumber literatur baik jurnal, buku, dan bahan referensi lainnya yang terpercaya untuk mendukung analisis penulis. Hasil kajian yang dilakukan menemukan banwa peran psikologi pendidikan agama Kristen di dalam pelaksanaan pembelajaran anak usia dini sangat besar karena menentukan metode dan strategi pembelajaran anak usia dini di masa pandemi, yaitu daring dan tatap muka dengan memperhatikan protokol kesehatan. Psikologi pendidikan di masa pandemi sangat signifikan diterapkan sebagai solusi dalam memahami kebutuhan anak-anak didik baik secara kognitif, afektif, psikomotorik serta spiritual.
\end{abstract}

Kata kunci: Psikologi, Pendidikan Agama Kristen, Anak Usia Dini, Pandemi, Covid-19

\section{ABSTRACT}

The purpose of writing this article is to see the extent of the role of psychology in Christian Religious Education in preparing learning methods for early childhood during the pandemic. This is because PAUD learning during the COVID-19 pandemic is a concern and challenge for teachers in carrying out learning. In addition, education in early childhood requires an adequate strategy. For this reason, teachers are required to try to understand the various problems faced in educating early childhood. The research method used is qualitative with data collection through direct observation by researchers and interviews with teachers and parents. The analysis process is carried out using various literature sources, both journals, books, and other trusted reference materials to support the author's analysis. The results of the research conducted found that the role of Christian religious education psychology in the implementation of early childhood learning was very large because it determined the methods and strategies of early childhood learning during the pandemic, namely online and face-to-face 
with a purpose. Pay attention to health protocols. Educational psychology during the pandemic is very significant as a solution in understanding students' cognitive, affective, psychomotor, and spiritual needs.

Keywords: Psychology, Christian Religious Education, Early Childhood, Pandemic, Covid-19

\section{PENDAHULUAN}

Sejak virus Covid-19 melanda dunia, wabah ini membawa dampak yang sangat besar bagi kegiatan manusia di seluruh dunia. Tidak terkecuali dalam bidang pendidikan di Indonesia. World Health Organization (WHO) pada tanggal 9 Maret 2020 menetapkan wabah ini sebagai pandemi yang diakibatkan oleh virus Covid 19 yang menyebar dengan cepat ke seluruh dunia, dimulai dari kota Wuhan, China. (COVID-19, 2021). Pemerintah Indonesia harus membentuk Gugus Tugas Penanganan Covid-19 berdasarkan Peraturan Presiden No. 7 tahun 2020 tanggal 13 Maret 2020. Gugus Tugas ini ditingkatkan fungsinya menjadi Komite Penanganan Corona Virus Disease 2019 berdasarkan Peraturan Presiden No. 82 tahun 2020 tanggal 20 Juli 2020 (S.T.P. COVID-19, 2020). Berdasarkan peraturan tersebut, pemerintah daerah di masingmasing propinsi, kabupaten dan kota mengeluarkan serangkaian regulasi untuk menekan laju penularan virus Covid-19. Sederet kebijakan yang diterapkan adalah pembatasan pergerakan masyarakat, penerapan protokol kesehatan yang ketat dan pengaturan ruang kerja dan kegiatan belajar mengajar dari rumah. Peraturan-peraturan ini bersifat mengikat bagi seluruh kegiatan masyarakat di Indonesia selama pandemi berlangsung.

Tetapi, dalam situasi ini penulis mengamati bahwa pelaksanaan pembelajaran bagi anak usia dini di masa pandemi ini bukan hal yang mudah untuk dilakukan. Karena mengajar anak usia dini berbeda dengan mengajar anak usia yang lebih besar. Salah satu penyebab terjadinya permasalahan dalam proses pembelajaran di masa pandemi adalah kurang adanya semangat dari anak dan kemampuan orang tua dalam mendampingi. Selain itu dalam kajian yang dilakukan oleh Lusye, mengatakan bahwa rata-rata anakanak yang belajar di masa pandemi sangat mudah bosan, karena aktivitas tersebut selalu dilakukan di dalam rumah sehingga hal ini menimbulkan ketidaknyamanan bagi peserta didik (Lusye et al., 2020).

Harus diakui bahwa pada umumnya manusia secara psikologis dan sosial 
memiliki aspek pikiran (mind), emosi (perasaan) dan kehendak (will). Sedangkan yang memengaruhi perilaku (behaviour) manusia adalah pikiran dan emosi (Simanjuntak, 2016). Menurut J. B. Watson yang juga merupakan tokoh pendiri paham behavioristik, meyakini bahwa psikologi membahas perilaku manusia yang terlihat. Hal yang sama menurut Gunarsa, (Achiruddin Saleh, 2018) seorang guru besar psikologi di Indonesia, psikologi mempelajari perilaku yang nyata, dapat dilihat atau diukur. Sedangkan pendidikan mempunyai tujuan mengembangkan potensi yang ada di dalam diri anak (manusia) termasuk aspek fisik dan psikis. Hal ini menunjukkan bahwa psikologi dan pendidikan mempunyai hubungan yang sangat penting dalam konteks pertumbuhan dan perkembangan manusia. Dari sinilah terlahir cabang ilmu baru yaitu psikologi pendidikan (Simanjuntak, 2016). Dengan kata lain, psikologi pendidikan bermanfaat dan berguna bagi guru untuk memahami perilaku peserta didik di dalam belajar, dengan mengetahui perilaku semua peserta didik, maka guru dapat memilih dan menggunakan metode pembelajaran yang sesuai untuk peserta didik, sehingga pembelajaran dapat dilaksanakan secara optimal (Sakerebau, 2018). Pendidikan Anak Usia Dini sebagai jenjang pendidikan yang paling dasar diharapkan menjadi pondasi kuat untuk membentuk sikap dan karakter peserta didik (fidesrinur. dkk., 2015). Berdasarkan buku Pedoman Sikap Pendidikan Anak Usia Dini dituliskan bahwa melalui pembiasaan dan keteladanan memiliki peran yang sangat penting dalam membangun karakter anak sejak usia dini. (fidesrinur. dkk., 2015). Salah satu pengembangan sikap terdapat pada aspek nilai dan moral yang terdapat dalam Kompetensi Inti Spiritual yaitu menerima ajaran agama yang dianut (Kemdikbud, 2015). Karena itu sebagai guru Pendidikan Agama Kristen di Taman Kanak-kanak harus memilih metode yang tepat agar pembelajaran sikap dan karakter yang sesuai dengan wawasan alkitabiah tetap tercapai dengan maksimal.

Berdasarkan penjelasan tersebut di atas maka manfaat dan kegunaan psikologi Pendidikan Agama Kristen saat ini sangat penting, karena mempelajari perilaku peserta didik dalam menghadapi situasi pandemi. Menurut Agung bahwa situasi psikologis seseorang di masa pandemi lebih cenderung takut, khawatir dan cemas (Agung, 2020). Menurut Cully bahwa Allah sumber dari kehidupan dan pengharapan dalam kehidupan ke-Kristenan (Cully, 1999). Di sini letak kelebihan dari pendidikan Agama Kristen 
dibandingkan dengan pendidikan umum, karena perbedaan perilaku keyakinan dalam proses pendidikan (Muanley, 2009). Oleh karena itu, dalam menerapkan metode pembelajaran pada pendidikan anak usia dini (PAUD) di masa pandemi sangat penting untuk diperhatikan, agar kompetensi capaiannya dapat tercapai dengan baik (UU No 20 Sistem Pendidikan Nasional, 2003).

Jadi sejak pemerintah memutuskan agar pembelajaran dilaksanakan dari rumah, maka pembelajaran untuk anak usia dini secara formal yaitu di Taman Kanak-kanak yang selama ini memakai sistem tatap muka tidak dapat berjalan dengan baik. Penetapan kebijakan belajar dengan sistem daring menyebabkan perubahan sistem pembelajaran di Taman Kanak-kanak. Tidak hanya itu, akibat belajar daring ini anakanak dan guru mengalami gangguan secara psikologi, dimana anak-anak dan guru dipaksa duduk di depan laptop sepanjang pembelajaran berjalan. Tetapi yang lebih mengejutkan lagi dalam kajian yang dilakukan oleh Pramana menjelaskan bahwa proses pembelajaran dari rumah sering kali monoton dan tidak seperti yang dilakukan di sekolah, di mana para guru dalam mengajar selalu diselingi nyanyi, tepuk tangan, cerita dan dongeng serta kreatifitas lainnya (Pramana, 2020). Anak tidak hanya senang dengan cerita-cerita khayal yang disampaikan oleh guru, tetapi ia sendiri juga senang bercerita kepada orang lain (Khairi, 2018).

Dengan melihat problematika tersebut di atas, maka tujuan penulisan artikel ini adalah untuk mengkaji sejauh mana peran psikologi Pendidikan Agama Kristen dalam menyiapkan metode pembelajaran kepada anak usia dini di masa pandemi ini.

Diharapkan setelah melakukan kajian ini dapat menambah wawasan guru atau para pendidik dalam memilih metode pembelajaran anak usia dini yang sesuai saat pandemi terutama pendidikan agama Kristen.

\section{METODE}

Dalam kajian ini, penulis menggunakan metode penelitian kualitatif dengan cara mengumpulkan data berdasarkan pengamatan pada keadaan yang sebenarnya, tanpa dipengaruhi pihak yang lain. Peneliti melakukan pengumpulan data dengan terjun secara langsung di lapangan sebagai pelaku, memakai dokumentasi pribadi, interview dengan guru kelas dari sekolah tempat peneliti mengajar, dan juga interview dengan 
orang tua yang diambil sesuai dengan situasi dan kondisi pembelajaran anak usia dini selama pandemi di mulai dari bulan Maret 2020 sampai Februari 2020 agar dapat membuat perbandingan kondisi pembelajaran anak usia dini untuk situasi sebelumnya sehingga hasilnya dapat memberikan wawasan baru yang bisa diterapkan pada masa kini (Shidiq \& Choiri, 2019). Selain itu, proses analisis yang dilakukan adalah menggunakan berbagai sumber literatur-literatur baik jurnal, buku dan bahan referensi lainnya yang terpercaya untuk mendukung analisis penulis. Langkah-langkah pengkajiannya adalah dengan mengumpulkan data dari dokumentasi pribadi, interview dengan guru kelas dan orang tua murid. Setelah itu diolah semua pengumpulan data dan menganalisis dengan berbagai macam sumber literature, buku, jurnal dan referensi lainnya yang dapat dipercaya. Menyajikan hasil data dengan guru kelas secara narasi dan mengambil kesimpulan hasil penelitian ini.

\section{HASIL DAN PEMBAHASAN}

\section{Hakikat Psikologi dan Psikologi Pendidikan Agama Kristen}

Setelah memahami persoalan yang ada di latar belakang, maka dalam bagian ini penulis menjelaskan tentang definisi psikologi. Psikologi pendidikan menurut Barlow didefinisikan sebagai pengetahuan yang berdasarkan pada riset psikologis yang menyediakan serangkaian sumber untuk membantu proses belajar mengajar secara efektif (Rahmat, 2021). Sedangkan Whiterington menyatakan psikologi pendidikan adalah studi sistematis tentang proses-proses dan faktor-faktor yang berhubungan dengan pendidikan manusia (Rahmat, 2021). Psikologi pendidikan menurut Sakerebau terletak pada anak didik, sebab perlakuan terhadap anak didik secara psikologis perlakuan tersebut harus selaras dengan keadaan anak didik, inilah yang disebut pendidikan. Dengan demikian persoalan psikologi yang berperan dalam proses pendidikan anak dapat terjawab apabila pendidik dapat memberikan bantuan kepada peserta didik agar berkembang secara wajar melalui bimbingan dan konseling, pemberian bahan pelajaran yang berstruktur dan berkualitas (Sakerebau, 2018). Kegunaan Psikologi Pendidikan dapat membantu peserta didik untuk mencapai tujuan pembelajaran, memahami karakteristik peserta didik, memahami proses belajar peserta didik, memilih dan menggunakan berbagai strategi dalam pembelajaran dan membantu 
melakukan penilaian terhadap kegiatan belajar atau perolehan hasil belajar yang telah dicapai peserta didik (Tas'adi, 2019). Sedangkan Pendidikan Agama Kristen menurut Homrighausen dan Enklaar, dimulai dari dipilihnya Abraham menjadi nenek moyang umat pilihan Tuhan dan pusat dari Pendidikan Agama Kristen adalah Allah itu sendiri, karena Allah adalah Pendidik Agung bagi umat-Nya (E.G.Homrighausen \& I.H.Enklaar, 1987). Berdasarkan pandangan tersebut maka dapat diartikan bahwa Pendidikan Agama Kristen adalah pengajaran yang menekankan pendidikan iman Kristen tentang Tuhan, moral, mental dan rohani peserta didik (Tafonao, 2018b). Oleh karena itu, sebagai seorang guru Kristen harus mengetahui tujuan Pendidikan Agama Kristen. Menurut Sitanggang dalam Tafonao mengatakan bahwa salah satu tujuan dari pendidikan Agama Kristen adalah memberikan pemahaman kepada siswa tentang Allah Tritunggal dan karya-Nya, sehingga siswa mampu merefleksi imannya di tengah-tengah masyarakat, akan menjadi orang Indonesia yang mampu menghayati imannya dan orang yang bertanggung jawab di tengah masyarakat dengan segala keberagamannya (Tafonao, 2018a). Dari tujuan inilah dapat diambil garis besarnya bahwa tujuan Pendidikan Agama Kristen bagi siswa adalah menanamkan rasa cinta kepada Tuhan sejak dari anak usia dini sehingga siswa akan memakai nilai-nilai ke-Kristenan dalam hidupnya baik sebagai pribadi maupun di tengah masyarakat.

Berdasarkan pembahasan yang sudah dijelaskan disinilah peran penting Psikologi Pendidikan Kristen terutama bagi guru Kristen di dalam proses belajar mengajar agar bisa menggunakan metode pembelajaran yang tepat. Dengan memahami Psikologi Pendidikan Kristen seorang guru Kristen dapat melihat dan mempertimbangkan psikologi peserta didik serta membantu dalam menentukan hal-hal tersebut di bawah ini:

Pertama, membuat tujuan pembelajaran dengan tepat. Sebagai seorang guru Kristen dengan pandangan Alkitabiah, psikologi Pendidikan Kristen dapat membantu guru lebih tepat dalam menentukan bentuk perubahan perilaku yang dikehendaki sebagai tujuan pembelajaran. Contoh: Guru akan mengajarkan tentang kisah Zakheus Sang Pemungut Cukai, diharapkan saat selesai pembelajaran ada perubahan tingkah laku peserta didik yaitu tentang kejujuran dan hati yang taat. Dan perubahan ini 
mengaplikasikan pemikiran Bloom tentang taksonomi perilaku individu dan mengaitkannya dengan teori-teori perkembangan individu (Muanley, 2009)

Kedua, memilih strategi atau metode pembelajaran yang sesuai. Dengan memahami psikologi Pendidikan Agama Kristen, guru dapat memilih strategi atau metode pembelajaran yang tepat dan sesuai, dan mampu mengaitkannya dengan karakteristik dan keunikan individu, jenis belajar dan gaya belajar dan tingkat perkembangan peserta didik (Hidayati, 2015).

Ketiga, memberikan bimbingan, memotivasi dan memfasilitasi belajar peserta didik. Tugas dan peran guru selain melaksanakan pembelajaran di kelas, namun juga membangun anak bertumbuh dalam keberadaannya (learning to be). Hal ini berarti bahwa guru harus membimbing anak dan mengenal serta menerima ajaran Firman Tuhan mengenai keunikan dirinya serta keunikan orang lain. Alkitab juga mengajarkan supaya anak bisa menerima dirinya sendiri dalam kasih Allah (Simanjuntak, 2016). Selain itu, menurut Tafonao bahwa Pendidikan Agama Kristen memiliki tugas yakni memuridkan serta membimbing anak-anak untuk memiliki hubungan pribadi dengan Tuhan. Itulah sebabnya para guru Kristen bertanggung jawab atas ketercapaian hal ini (Tafona'o, 2019).

Keempat, menciptakan suasana pembelajaran yang konduksif. Sesuai dengan Permendikbud no 137 Standar Pendidikan Anak Usia Dini pasal 13 ayat a. mengenai pelaksanaan pembelajaran anak usia dini dilakukan dengan nyaman, inspiratif, menyenangkan dan berpusat kepada anak (Aghnaita, 2017). Berdasarkan penjelasan ini maka jelas bahwa peran Psikologi Pendidikan Agama Kristen begitu penting bagi guru untuk bisa merancang dan memilih metode pembelajaran yang tepat bagi anak usia dini.

\section{Karakteristik Pembelajaran Anak Usia Dini}

Pembelajaran anak usia dini yang selama ini dilakukan dengan sistem tatap muka sangat efektif. Hal ini karena dalam proses pembelajaran anak usia dini masih membutuhkan bimbingan guru secara langsung, karena guru merupakan pelaksana sekaligus pemandu jalannya proses pembelajaran di dalam kelas. Berdasarkan ilmu psikologi anak, bahwa usia dini masih harus menyesuaikan dengan lingkungannya, kehadiran guru membuat dia lebih nyaman karena ada seseorang yang akan 
mengarahkan dan memberikan bantuan jikalau diperlukan. (Wulandari \& Purwanta, 2020). Dengan melakukan pembelajaran secara langsung di kelas, guru dapat lebih mudah memberikan instruksi kepada anak secara langsung terkait berbagai aktivitas pembelajaran yang sedang dilakukan, sehingga membuat anak-anak juga lebih mudah dalam memahami instruksi guru, yang pada akhirnya membuat aspek-aspek perkembangan anak berkembang lebih optimal. Selain memberikan kemudahan dalam pelaksanaan proses pembelajaran, pembelajaran yang dilakukan secara langsung di dalam kelas terbukti memiliki berbagai manfaat yang positif pada semua pencapaian perkembangan anak, yaitu aspek nilai agama dan moral, aspek kognitif, aspek motorik baik motorik halus dan motorik kasar, aspek bahasa, aspek sosial emosional, aspek seni. Oleh karena itu, dalam melaksanakan proses pembelajaran tatap muka secara langsung di sekolah guru harus melaksanakannya dengan seoptimal mungkin, sehingga proses pembelajaran dapat terlaksana dengan baik dan sekaligus dapat mengoptimalkan aspekaspek perkembangan anak (Wulandari \& Purwanta, 2020).

Berdasarkan Peraturan Presiden (Perpres) Nomor 60 Tahun 2013, yang disebut anak usia dini adalah bayi yang baru lahir hingga anak-anak yang belum genap berusia 6 tahun. Dalam pemantauan tumbuh-kembangnya, kelompok usia ini dibagi lagi menjadi janin dalam kandungan sampai lahir lahir sampai dengan usia 28 hari, usia 1 sampai 24 bulan, dan usia 2 sampai 6 tahun. Anak usia dini adalah anak yang berada pada usia 0-8 tahun. Khairi menjelaskan bahwa, anak usia dini merupakan anak yang berusia antara 3-6 tahun. Anak usia dini adalah anak yang berusia antara 0 sampai 6 tahun, termasuk mereka yang masih berada dalam kandungan yang sedang berada dalam proses pertumbuhan dan perkembangan fisik, mental, kepribadian, dan intelektualnya, di mana pada usia tersebut sering disebut dengan 'golden age'. Pertumbuhan anak usia dini mempunyai tahapan-tahapan perkembangan untuk setiap aspek dalam tingkatan usianya (Khairi, 2018).

Berdasarkan penjelasan tersebut, maka berikut ini adalah beberapa karakteristik anak usia dini menurut beberapa pendapat dari para ahli, yakni: (1) Unik, artinya sifat antara anak yang satu dengan yang lain berbeda. Anak memiliki bawaan, minat kapabilitas, dan latar belakang kehidupan masing-masing. (2) Egosentris, yaitu anak memandang bahwa segala sesuatu yang terkait pada dirinya adalah penting. 3) Aktif dan 
energik, yaitu anak seolah-olah tidak pernah lelah dan tidak pernah berhenti dalam aktivitasnya selama terjaga. (4) Rasa ingin tahu yang tinggi dan semangat terhadap banyak hal, yaitu anak sangat bersemangat di dalam memperhatikan, menanyakan, membicarakan tentang berbagai banyak hal terutama pengalaman-pengalaman baru. (5) Eksploratif dan berjiwa petualang, yaitu anak selalu terdorong oleh rasa ingin tahu, senang berjelajah dan mencoba hal-hal yang baru. (5) Selalu ingin tahu (eksploratif) dan berjiwa petualang, selalu ingin mencoba hal-hal yang baru. (6) Spontan yaitu tindakan yang langsung dilakukan sebagai ekspresi dari apa yang ada dalam perasaan dan pikirannya. (7) memiliki imajinasi dan fantasi yang kaya, anak senang bercerita dengan imajinasi yang dia buat sendiri dan juga senang mendengarkan cerita khayal dari orang lain. (8) Mudah frustasi dan mudah marah, anak masih mudah menangis dan lebih cenderung marah jika keinginannya tidak dipenuhi. (9) Masih ceroboh dalam arti karena belum memiliki pertimbangan yang baik sehingga anak kadang berhubungan dengan hal-hal yang membahayakan dirinya. (10) Tidak mudah fokus dalam arti anak masih memiliki daya perhatian yang pendek kecuali hal - hal yang membuatnya menarik dan menyenangkan bagi dirinya. (11) Semangat dalam belajar dan banyak belajar dari pengalaman, sehingga anak akan mengalami perubahan tingkah laku pada dirinya. (12) Semakin menunjukkan minat terhadap teman, yaitu anak mulai menunjukkan untuk bekerja sama dan berhubungan dengan teman-temannya. Hal ini beriringan dengan bertambahnya usia dan perkembangan yang dimiliki oleh anak (Kartono, 1990) dan (Sofia \& Hartati, 2005).

Berangkat dari uraian di atas, maka metode pembelajaran anak usia dini menurut pendapat Elyyil Akbar adalah sebagai berikut : a) metode bercerita, yaitu cara bertutur kata dan penyampaian cerita atau memberikan penjelasan tentang suatu cerita kepada anak secara lisan. Tujuan metode bercerita agar anak belajar untuk mendengarkan, mengerti isi cerita, menceritakan setiap sifat tokohnya dan pastinya tujuan dari pelajaran pada hari itu. Metode bercerita menurut survei, termasuk metode pembelajaran yang paling sering digunakan saat tatap muka. b) metode ceramah, adalah kegiatan guru menerangkan tentang materi pembelajaran. Dari metode ceramah ini, guru dapat melatih anak untuk belajar fokus dengan cara mendengarkan penjelasan materi belajar. c) metode tanya jawab merupakan pembelajaran dua arah dalam arti guru dan siswa saling 
bertanya dan menjawab. Dari metode tanya jawab ini guru dapat melatih keberanian siswa dalam mengungkapkan pendapat. d) Metode karyawisata yaitu metode dengan mengunjungi tempat-tempat yang sesuai dengan pelajaran atau tema pelajaran saat itu. Metode ini melatih siswa untuk lebih menjelajah atau mencari lebih banyak informasi mengenai pelajaran atau tema pelajaran yang dipelajari. e) Metode demonstrasi adalah metode di mana guru menunjukkan cara atau memperagakan suatu cara untuk mengerjakan ketrampilan atau tugas yang harus diselesaikan siswa. f) Metode sosiodrama atau bermain peran yaitu metode yang mengajarkan kepada anak untuk berperan menjadi orang atau tokoh sesuai dengan kegiatan atau permainan yang dilakukan sesuai dengan tema pelajaran. Misal : bermain jual beli sayur dan buah di pasar, bermain dokter dan pasien, dan lain-lain. g) Metode eksperimen adalah metode yang memberikan pengalaman kepada anak untuk melakukan percobaan dan mengamati akibatnya. Misal : membuat campuran warna, balon yang ditiup, tanaman yang mendapat sinar matahari dan tidak mendapatkan sinar matahari, dan lain-lain. h) Metode proyek yaitu metode yang mengajarkan anak untuk memakai alam sekitar dan kegiatan sehari-hari menjadi bahan pembahasan pelajaran melalui berbagai kegiatan. i) Metode pemberian tugas adalah metode agar anak dapat menyelesaikan tugas yang disiapkan guru. j) Metode bermain adalah metode yang harus ada di pembelajaran anak usia dini karena merupakan prinsip dasar pendidikan anak usia dini (Akbar, 2020)

\section{Tantangan Pelaksanaan Pembelajaran Bagi Anak Usia Dini di Masa Pandemi}

Sebelum adanya wabah Covid-19 pembelajaran di Taman Kanak Kanak memakai sistem tatap muka atau bertemu langsung dan semua metode pembelajaran yang dijelaskan di atas dapat dilaksanakan karena guru dapat secara langsung melihat sikap dan tingkah laku peserta didik. Pandemi Covid-19 telah membuat sistem pendidikan berubah dari tatap muka atau bertemu langsung menjadi sistem daring, dalam jaringan (Astuti \& Harun, 2021). Sistem daring ini berlaku untuk semua jenjang pendidikan, baik dari TK hingga Perguruan Tinggi.

Dari hasil penelitian yang penulis lakukan, diperoleh hasil bahwa hal ini menjadi kendala bagi pelaksanaan pendidikan bagi anak usia dini (PAUD). Pendidikan Anak Usia Dini (PAUD) pada jalur pendidikan formal dapat berupa Taman Kanak-Kanak dan 
(TK) /Raudathul Atfhal (RA). Adapun PAUD pada jalur pendidikan nonformal dapat berupa Kelompok Bermain (KB), Taman Penitipan Anak (TPA), atau bentuk lain yang sederajat (Supena et al., 2018). Dalam penelitian ini, Pendidikan Anak Usia Dini yang dimaksud adalah pada jalur formal yaitu Taman Kanak-kanak. Beberapa alasan yang penulis dapatkan adalah

1) Anak Usia Dini dalam hal ini pembelajaran yang berlangsung di Taman Kanakkanak belum terbiasa memakai sistem daring dalam pembelajaran. Hal ini terlihat dari hasil pengamatan dan survei penulis, sebanyak 29 peserta didik di Taman Kanak-kanak yang menjadi observasi, yang mengikuti pembelajaran secara daring rata-rata berjumlah 10 peserta didik. Guru memakai aplikasi Whatsapp untuk video call dan sebanyak 10 peserta didik yang konsisten ikut dan mengikuti dengan baik selama 30 menit pelajaran. Peserta didik yang lain, mengikuti sebentar rata-rata 5 sampai 10 menit setelah itu mereka akan melakukan aktivitas sendiri seperti larilari di ruangan, tiduran bahkan ada yang tidak mau lagi belajar.

2) Peran orang tua sebagai guru saat di rumah tidak berjalan dengan maksimal (Tabi, 2020). Berdasarkan pengamatan dan survei penulis, dari 29 peserta didik yang diobservasi sekitar 15 peserta didik yang konsisten mengerjakan setiap tugas dan pekerjaan dari guru, 10 peserta didik belum konsisten dikarenakan latar belakang pendidikan orang tua yang tidak bisa menemani atau mengajar ke peserta didik, 4 orang benar-benar tidak terjangkau karena orang tua tidak mau mengajari peserta didik.

3) Orang tua lebih memberikan prioritas pemakaian gawai untuk bekerja dan keperluan belajar anak yang lebih besar atau tinggi jenjangnya. Ini juga berdasarkan survei, semua orang tua peserta didik di Taman Kanak-kanak mempunyai gawai namun gawai tersebut dipakai untuk bekerja atau dipakai untuk anak yang lebih tinggi jenjangnya seperti SD, SMP dan SMA. Anggapan orang tua bahwa anak usia dini belum begitu penting dengan materi pelajarannya dibandingkan jenjang yang lebih tinggi. 4) Hilangnya 'sentuhan' guru kepada peserta didik. Hal ini sangat terasa bagi guru Taman Kanak-kanak, terbiasa dengan memberikan 'sentuhan' terutama saat menjelaskan materi pembelajaran. 
Menjadi tantangan tersendiri bagi guru Taman Kanak-Kanak dalam masa pandemi ini karena metode pembelajaran harus berubah menyesuaikan dengan daring dan terkesan mendadak. Penggunaan sistem pembelajaran yang memakai daring dalam arti aplikasi media internet yang belum tentu dikuasai oleh guru dan orang tua demikian juga dengan masalah biaya kuota, pada awal pandemi sangat menjadi masalah terutama untuk orang tua karena harus mengeluarkan biaya sendiri (Ayuni et al., 2020). Proses pembelajaran melalui platform internet baik lewat WhatsApp, Zoom, Teams, Google meet, atau dengan yang lain belum tentu maksimal dibandingkan jika melalui tatap muka. Belum masalah sinyal yang kadang kala hilang atau lancar, bukan saja menjadi kendala namun benar-benar menguras emosi baik pada saat pembelajaran sedang berlangsung atau pun saat bertemu dengan peserta didik. Sehingga dalam menghadapi pembelajaran anak usia dini di masa pandemi ini dibutuhkan kesabaran dan kecermatan agar dapat menemukan solusi terbaik (Pramana, 2020).

\section{Penerapan Peran Psikologi Pendidikan Agama Kristen Di Masa Pandemi}

Setelah memahami penjelasan sebelumnya, maka dalam bagian ini penulis menjelaskan bahwa melihat karakteristik anak usia dini dan beberapa tantangan yang sudah dijabarkan bahwa peran Psikologi Pendidikan Agama Kristen dalam pembelajaran anak usia dini di masa pandemi ini sangat besar, karena guru harus bisa melihat perubahan perilaku peserta didik saat ini dengan tidak bisa 'menyentuh' secara fisik atau melihat secara fisik namun harus tetap memakai strategi pembelajaran yang tepat sehingga tujuan dan hasil perkembangan peserta didik tetap dapat tercapai dengan maksimal (Pramana, 2020). Menurut Homrighausen mengatakan bahwa tugas guru Kristen tidak hanya sekedar fasilitator, guru tidak hanya menyampaikan konten atau pengetahuan sebagai fakta saja. Namun guru harus mengambil kesempatan pembelajaran sebagai sarana untuk membawa peserta didik berjumpa dengan kebenaran yaitu Tuhan Yesus sendiri. (Nakamnanu, 2020). Karena itu guru juga harus mengenali nilai intrinsik bawaan setiap muridnya termasuk keunikannya dan menyadari bahwa keunikan ini menuntut saling ketergantungan satu dengan yang lain. Dengan kata lain bahwa guru dituntut mengenali berbagai kepribadian dan cara belajar murid yang beragam, sehingga metode pembelajaran yang dilakukan dapat tepat sehingga setiap 
murid memiliki kesempatan yang sama untuk dengan maksimal mengembangkan talenta dan berespon terhadap panggilan Allah dalam hidup mereka (SLH SDH, 2020) Pemahaman guru Kristen terhadap arti sebenarnya manusia dalam perspektif Alkitabiah akan membuat peta tentang karakteristik setiap manusia, dalam hal ini anak usia dini, akan menjadi landasan dan acuan bagi guru dalam bersikap, menyusun strategi, metode dan teknik serta memilih pendekatan dalam merancang pembelajaran

Oleh karena itu penerapan psikologi dalam Pendidikan Agama Kristen sangat penting seperti yang ungkapkan oleh Ronal Konteskey dalam Psychology from a Christian Persfective pada tahun 1980 dan General Psychology for Christian Counselor pada tahun 1983 yang menyatakan bahwa Allah adalah pencipta alam semesta, Maha Pribadi dan tidak terbatas sedangkan manusia sebagai dasar pengetahuan dan ciptaan berpribadi kompleks (Simanjuntak, 2016). Pusat perhatian dari psikologi adalah manusia, binatang dan ciptaan lain. Manusia adalah ciptaan Allah mirip dengan Sang Khalik tetapi serba terbatas. Karena hidup dalam dunia ini dengan menghirup udara yang sama serta mengandalkan energi dari bumi manusia mirip dengan hewan, tumbuhan dan ciptaan lain. Psikologi yang mempelajari manusia sebagai pribadi (Strukturalisme, Gestalt, dan Humanistik) dan ada pula psikologi yang memandang manusia identik dengan hewan saja (Fungsionalisme, Psikoanalisis, dan Behavioris-me) (Simanjuntak, 2016). Menurut Muanley bahwa psikologi Pendidikan Agama Kristen merupakan pengkajian perilaku peserta didik dalam situasi pendidikan Agama Kristen yang didasarkan pada Alkitab (Muanley, 2012). Berdasarkan penjelasan tersebut maka penulis menyimpulkan bahwa penerapan peran Psikologi Pendidikan Agama Kristen sangat penting bagi guru dalam menentukan tujuan, metode, pendekatan dalam pembelajaran dengan mempelajari sikap dan tingkah laku peserta didik dalam hal ini adalah anak usia dini, agar tujuan pembelajaran dapat tercapai.

Selanjutnya, setelah memahami berbagai penjelasan di atas, maka berikut ini adalah metode pembelajaran yang sudah dilaksanakan selama pandemi atau daring, tetapi perlu diketahui bahwa pembelajaran ini ada yang berjalan dengan maksimal namun ada yang tidak bisa berjalan dengan maksimal, berdasarkan pengamatan dan hasil observasi penulis bisa selama pandemi, yaitu: 


\begin{tabular}{|c|c|c|}
\hline $\begin{array}{c}\text { Metode } \\
\text { pembelajaran }\end{array}$ & $\begin{array}{l}\text { Sebelum pandemik } \\
\text { (tatap muka) }\end{array}$ & Selama pandemi (daring) \\
\hline $\begin{array}{l}\text { Metode } \\
\text { bercerita }\end{array}$ & $\begin{array}{l}\text { Dilakukan. Penilaian bisa } \\
\text { dilakukan secara langsung } \\
\text { dengan tanya jawab atau } \\
\text { mengerjakan tugas }\end{array}$ & $\begin{array}{l}\text { Dapat dilakukan memakai rekaman } \\
\text { video atau guru memakai ppt sebagai } \\
\text { media bercerita. Penilaian bisa } \\
\text { dilakukan dengan memberikan } \\
\text { pertanyaan refleksi sederhana di } \\
\text { bagian terakhir video }\end{array}$ \\
\hline Metode ceramah & Dilakukan. & $\begin{array}{l}\text { Dapat dilakukan dengan cara rekaman } \\
\text { video. Harus tetap diberikan } \\
\text { pertanyaan di bagian akhir video, agar } \\
\text { guru mendapatkan feedback. }\end{array}$ \\
\hline $\begin{array}{c}\text { Metode tanya } \\
\text { jawab }\end{array}$ & Dilakukan & $\begin{array}{l}\text { Dapat dilakukan, jikalau memakai VC } \\
\text { WhatsApp, Teams, Zoom, Google } \\
\text { meeting, atau aplikasi yang lain } \\
\text { walaupun tidak maksimal karena } \\
\text { sebagian peserta didik tidak bisa } \\
\text { mengikuti dengan baik }\end{array}$ \\
\hline $\begin{array}{c}\text { Metode } \\
\text { karyawisata }\end{array}$ & Dilakukan & $\begin{array}{l}\text { Tidak dapat dilakukan mengingat } \\
\text { harus menghindari kerumunan dan } \\
\text { daerah zona merah covid } 19\end{array}$ \\
\hline $\begin{array}{c}\text { Metode } \\
\text { demonstrasi }\end{array}$ & Dilakukan & $\begin{array}{l}\text { Dapat dilakukan, dengan cara guru } \\
\text { mengirimkan video tentang langkah- } \\
\text { langkah percobaan, dan peserta didik } \\
\text { mengirimkan video saat melakukan } \\
\text { percobaan sesuai instruksi guru }\end{array}$ \\
\hline $\begin{array}{c}\text { Metode } \\
\text { sosiodrama }\end{array}$ & Dilakukan & $\begin{array}{l}\text { Dapat dilakukan walaupun tidak } \\
\text { maksimal. Guru harus bekerja sama } \\
\text { dengan orang tua agar tujuan } \\
\text { pembelajaran dalam peran dapat } \\
\text { berjalan dengan baik. Bentuk } \\
\text { penilaiannya berbentuk video, dan hal } \\
\text { inilah yang menjadi kendala karena } \\
\text { tidak semua peserta didik mempunyai } \\
\text { gawai android. }\end{array}$ \\
\hline $\begin{array}{c}\text { Metode } \\
\text { eksperimen }\end{array}$ & Dilakukan & $\begin{array}{l}\text { Dapat dilakukan dengan cara guru } \\
\text { mengirimkan video cara melakukan } \\
\text { eksperimen dan peserta didik juga } \\
\text { mengirimkan video agar guru dapat } \\
\text { menilai }\end{array}$ \\
\hline Metode proyek & Dilakukan & $\begin{array}{l}\text { Dapat dilakukan. Peserta didik dapat } \\
\text { memanfaatkan lingkungan sekitar } \\
\text { rumah sebagai bahan pembahasan }\end{array}$ \\
\hline
\end{tabular}




\begin{tabular}{|c|l|l|}
\hline $\begin{array}{c}\text { Metode } \\
\text { pembelajaran }\end{array}$ & \multicolumn{1}{|c|}{$\begin{array}{c}\text { Sebelum pandemik } \\
\text { (tatap muka) }\end{array}$} & \multicolumn{1}{c|}{ Selama pandemi (daring) } \\
\hline $\begin{array}{c}\text { Metode } \\
\text { pemberian tugas }\end{array}$ & Dilakukan & dalam pembelajaran. \\
& & $\begin{array}{l}\text { Tidak dapat dilakukan secara } \\
\text { maksimal. Tidak semua peserta didik } \\
\text { dapat mengerjakan tugas tepat pada } \\
\text { waktunya, tergantung dari orang tua } \\
\text { masing-masing karena masih ada } \\
\text { orangtua yang bekerja sampai jam } \\
\text { 17.00 WIB }\end{array}$ \\
\hline Metode bermain & Dilakukan & $\begin{array}{l}\text { Tidak dapat dilakukan dengan } \\
\text { maksimal karena guru tidak bisa } \\
\text { memantau langsung }\end{array}$ \\
\hline
\end{tabular}

Tabel 1. Berbagai macam metode pembelajaran anak usia dini di masa pandemi

Selain metode pembelajaran di atas yang memakai sistem daring, ada beberapa strategi pembelajaran yang bisa dilakukan selama masa pandemi berdasarkan karakteristik anak usia dini yang tetap membutuhkan 'sentuhan' selama pandemi yaitu :

\begin{tabular}{|c|c|c|}
\hline Strategi & Kelebihan & Kelemahan \\
\hline $\begin{array}{l}\text { Sistem Pengambilan dan } \\
\text { Pengumpulan Tugas } \\
\text { - } \quad \text { Orang tua seminggu } \\
\text { sekali datang ke } \\
\text { sekolah mengambil } \\
\text { tugas dan } \\
\text { mengumpulkan tugas } \\
\text { untuk minggu } \\
\text { sebelumnya }\end{array}$ & $\begin{array}{l}\text { - } \text { Guru tetap } \\
\text { mempersiapkan } \\
\text { Rencana Mingguan, } \\
\text { buku tugas dan lembar } \\
\text { kerja siswa setiap } \\
\text { minggunya } \\
\text { Komunikasi antara } \\
\text { orang tua dan guru } \\
\text { tetap terjalin karena } \\
\text { orang tua akan selalu } \\
\text { datang ke sekolah } \\
\text { walaupun satu kali } \\
\text { dalam seminggu }\end{array}$ & 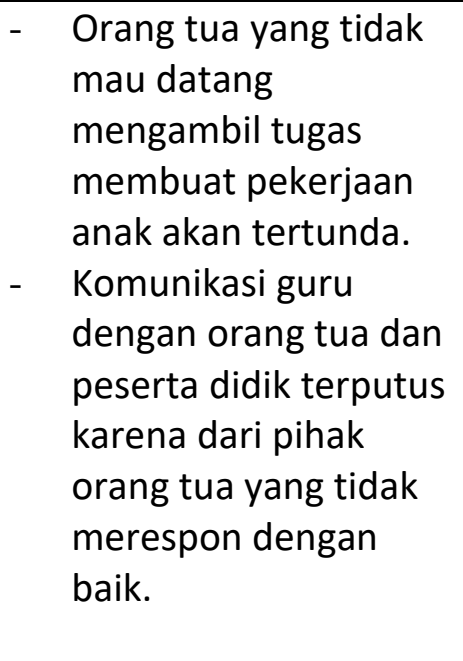 \\
\hline $\begin{array}{l}\text { Sistem Guru Keliling } \\
\text { (Guling) } \\
\text { - } \quad \text { diprioritaskan untuk } \\
\text { peserta didik yang tidak } \\
\text { pernah mengumpulkan } \\
\text { tugas atau orang tua } \\
\text { tidak mempunyai gawai } \\
\text { - } \\
\text { selain itu untuk peserta } \\
\text { didik pada saat } \\
\text { pembelajaran daring } \\
\text { tidak nyaman atau }\end{array}$ & $\begin{array}{l}\text { Guru berkeliling ke rumah } \\
\text { peserta didik satu persatu } \\
\text { dan bisa bertemu langsung, } \\
\text { sangat membantu untuk } \\
\text { peserta didik yang tidak } \\
\text { pernah mengumpulkan } \\
\text { tugas (prioritas), melihat } \\
\text { kondisi peserta didik secara } \\
\text { langsung, dan bisa secara } \\
\text { langsung melihat } \\
\text { perkembangan peserta }\end{array}$ & $\begin{array}{l}\text { - } \text { Guru harus } \\
\text { mempunyai kendaraan } \\
\text { sendiri atau bisa } \\
\text { mengendarai sendiri } \\
\text { alat transportasi untuk } \\
\text { bisa menjangkau } \\
\text { rumah peserta didik } \\
\text { yang jauh. } \\
\text { Biaya transport yang } \\
\text { harus didukung oleh } \\
\text { lembaga atau sekolah }\end{array}$ \\
\hline
\end{tabular}




\begin{tabular}{|c|c|c|}
\hline Strategi & Kelebihan & Kelemahan \\
\hline $\begin{array}{l}\text { belum terbiasa dan } \\
\text { tidak mau } \\
\text { mengikutinya. }\end{array}$ & $\begin{array}{l}\text { didik dalam perkembangan } \\
\text { sosial emosional, nilai } \\
\text { agama dan moral, motorik } \\
\text { dan bahasa. }\end{array}$ & \\
\hline $\begin{array}{l}\text { Sistem kelompok belajar } \\
\text { - } \text { Ditujukan untuk } \\
\text { peserta didik yang ada } \\
\text { di satu kampung atau } \\
\text { berdekatan lokasi } \\
\text { rumahnya dapat } \\
\text { dikumpulkan bertemu } \\
\text { di salah satu rumah } \\
\text { peserta didik, maksimal } \\
3 \text { peserta didik dan } \\
\text { guru berkunjung di } \\
\text { rumah salah satu } \\
\text { peserta didik yang telah } \\
\text { ditentukan }\end{array}$ & $\begin{array}{l}\text { Guru bisa bertemu } \\
\text { langsung dengan peserta } \\
\text { didik, memberikan materi } \\
\text { pembelajaran dan tugas } \\
\text { secara langsung. Guru } \\
\text { dapat langsung melihat } \\
\text { perkembangan peserta } \\
\text { didik dan menilai sesuai } \\
\text { dengan aspek } \\
\text { perkembangan }\end{array}$ & $\begin{array}{l}\text { Jika satu anak tidak bisa } \\
\text { datang akan } \\
\text { mempengaruhi anak yang } \\
\text { lain sehingga kadang } \\
\text { membuat pembelajaran } \\
\text { menjadi tidak konduksif }\end{array}$ \\
\hline $\begin{array}{l}\text { Sistem shift ke sekolah } \\
\text { - } \quad \text { Sekolah membuat } \\
\text { jadwal masuk seminggu } \\
\text { 1-2 pertemuan dengan } \\
\text { maksimal peserta didik } \\
\text { yang masuk sejumlah } 5 \\
\text { anak }\end{array}$ & $\begin{array}{l}\text { Seperti di atas, guru dapat } \\
\text { memberikan dan melatih } \\
\text { pembiasaan yang ada di } \\
\text { sekolah secara langsung } \\
\text { walaupun bertahap, seperti } \\
\text { baris di depan kelas, } \\
\text { berdoa sebelum dan } \\
\text { sesudah belajar, berdoa } \\
\text { waktu makan, mencuci } \\
\text { tangan sendiri dan } \\
\text { membereskan alat-alat } \\
\text { belajar dan makan mereka } \\
\text { sendiri. }\end{array}$ & $\begin{array}{l}\text { Orang tua yang tidak bisa } \\
\text { mengantar ke sekolah } \\
\text { terutama masalah } \\
\text { transport dalam arti orang } \\
\text { tua bisa mengantarkan } \\
\text { peserta didik karena } \\
\text { jadwal masuk sekolah } \\
\text { yang selalu berubah-ubah } \\
\text { berdasarkan jadwal dari } \\
\text { sekolah }\end{array}$ \\
\hline
\end{tabular}

Tabel 2. Strategi Pembelajaran di masa pandemi.

Selain metode dan strategi pembelajaran yang mengalami penyesuaian dan perubahan disesuaikan dengan kebutuhan di masa pandemi, guru juga harus meningkatkan diri dalam hal ketrampilan terutama dalam era digital yaitu: (a). harus belajar dan beradaptasi dengan teknologi informasi terutama aplikasi meeting seperti Zoom, Google meeting, Teams dan WhatsApp. Selain untuk pembelajaran daring bisa digunakan dengan metode bercerita dengan durasi yang tidak begitu lama sekitar 10 menit. Yang sudah dilakukan oleh beberapa Taman Kanak-kanak adalah memakai Copyright @ 2021 | Jurnal Vox Dei | ISSN: 2657-0777 (print), 2723-2751 (online) 
aplikasi WhatsApp dan Zoom meeting (Ayuni et al., 2020) Selain memakai aplikasi meeting juga guru dituntut untuk belajar membuat video singkat mengenai pembelajaran, selain itu juga kemampuan dalam membuat slide atau ppt interaktif agar bisa membuat peserta didik lebih bersemangat dalam belajar melalui daring. (b). lebih kreatif dan inovatif. Berdasarkan Keputusan Menteri Pendidikan no 719 pada bulan Agustus 2020 mengenai kurikulum baik dari Taman Kanak-kanak sampai Perguruan Tinggi tentang pembelajaran anak yang disesuaikan dengan konteks masa pandemi ini menuntut guru untuk harus kreatif dan inovatif (Kemendikbud, 2020). Guru dapat memberikan tugas seperti menanam sayur kangkung memakai polybag dan hasilnya di masak sendiri menjadi tumis sayur kangkung, membuat karya tangan memakai barang atau benda di sekitar rumah atau lingkungan peserta didik, seperti membuat kolase dengan memakai daun kering, dan masih banyak lagi (Ayuni, 2020). (c). memiliki kemampuan berkomunikasi dengan baik kepada orang tua murid. Komunikasi ini penting dalam membantu kelancaran proses belajar di rumah. Karena orang tua akan menjadi 'guru' saat anak belajar di rumah dan guru akan mendapatkan laporan perkembangan anak paling banyak dari orang tua. Disinilah peran Psikologi Pendidikan Agama Kristen besar karena akan memudahkan guru dalam bersikap menghadapi orang tua sebagai rekan sekerja dalam pendidikan anak.

\section{SIMPULAN}

Berdasarkan kajian di atas maka dapat disimpulkan bahwa peran psikologi pendidikan agama Kristen di dalam pelaksanaan pembelajaran anak usia dini sangat besar karena menentukan metode dan strategi pembelajaran anak usia dini. Melihat karakteristik anak usia dini, strategi pembelajaran di masa pandemi ini bisa dilakukan dengan cara daring dan tatap muka dengan memperhatikan jumlah peserta didik maksimal 5 anak dan menjalankan protokol kesehatan. Sistem daring tetap memakai aplikasi WhatsApp sebagai aplikasi yang paling mudah digunakan baik bagi guru maupun orang tua, selain itu juga bisa memakai aplikasi Zoom meeting dan Google meeting. Guru juga harus lebih kreatif dan belajar membuat video pembelajaran yang singkat namun tetap jelas tujuannya serta membuat slide yang menarik agar pada saat pembelajaran melalui daring peserta didik tetap terpenuhi rasa ingin tahunya yang besar 
dan tetap mengikuti dengan nyaman di dalam belajar. Sistem tatap muka bisa dilakukan dengan cara sistem pengambilan dan pengumpulan tugas oleh orang tua setiap seminggu sekali, guru keliling di rumah peserta didik, belajar kelompok dengan mengumpulkan peserta didik dalam satu area dan pergantian jadwal masuk belajar di sekolah. Penyederhanaan kurikulum selama pembelajaran masa pandemi lebih ditekankan tentang ketrampilan hidup atau kecakapan peserta didik di dalam menghadapi situasi masa pandemi dengan pemberian tugas yang disesuaikan dengan kondisi rumah atau lingkungan di sekitar rumah peserta didik.

\section{DAFTAR PUSTAKA}

Achiruddin Saleh, A. (2018). Pengantar Psikologi. Aksara Timur.

Aghnaita, A. (2017). Perkembangan Fisik-Motorik Anak 4-5 Tahun Pada

Permendikbud No. 137 Tahun 2014 (Kajian Konsep Perkembangan Anak). Al-

Athfal : Jurnal Pendidikan Anak, 3(2), 219. Https://Doi.Org/10.14421/Al-

Athfal.2017.32-09

Agung, I. M. (2020). Memahami Pandemi Covid-19 Dalam Perspektif Psikologi Sosial. Psikobuletin:Buletin Ilmiah Psikologi, 1(2), 68-84. Http://Ejournal.UinSuska.Ac.Id/Index.Php/Psikobuletin/Article/View/9616/5058

Akbar, E. (2020). Metode Belajar Anak Usia Dini. Kencana.

Https://Books.Google.Co.Id/Books?Id=Myp1dwaaqbaj\&Printsec=Frontcover\#V= Onepage \&Q\&F=False

Astuti, I. Y., \& Harun. (2021). Tantangan Guru Dan Orang Tua Dalam Kegiatan Belajar Dari Rumah Anak Usia Dini Pada Masa Pandemi Covid-19. Jurnal Obsesi: Jurnal Pendidikan Anak Usia Dini, 5(2).

Https://Doi.Org/Https://Doi.Org/10.31004/Obsesi.V5i2.808

Ayuni, D., Marini, T., Fauziddin, M., \& Pahrul, Y. (2020). Kesiapan Guru Tk

Menghadapi Pembelajaran Daring Masa Pandemi Covid-19. Jurnal Obsesi : Jurnal

Pendidikan Anak Usia Dini, 5(1), 414. Https://Doi.Org/10.31004/Obsesi.V5i1.579

Covid-19, S. T. P. (2021). Apa Yang Dimaksud Dengan Pandemi?

Https://Covid19.Go.Id/Tanya-Jawab?Search=Apa Yang Dimaksud Dengan

Pandemi 
Cully, I. V. (1999). Dinamika Pendidikan Kristen (6th Ed.). Bpk Gunung Mulia.

E.G.Homrighausen, \& I.H.Enklaar. (1987). Pendidikan Agama Kristen (9th Ed.). Bpk Gunung Mulia.

Fidesrinur. Dkk. (2015). Pedoman Penanaman Sikap Pendidikan Anak Usia Dini. 24.

Hidayati, F. (2015). Metode Pembelajaran Paud. Kompasiana.Com.

Https://Www.Kompasiana.Com/Hidayatifahmi/54f70158a3331100258b457b/Meto de-Pembelajaran-Paud

Kartono, K. (1990). Psikologi Perkembangan Anak. Cv. Mandar.

Kemdikbud. (2015). Direktorat Pembinaan Pendidikan Anak Usia Dini Buku Penilaian Pembelajaran. 021, 5.

Kemendikbud. (2020). Salinan Keputusan Menteri Pendidikan Dan Kebudayaan Nomor 719 Lpl2o2o. 021, 1-10.

Khairi, H. (2018). Karakteristik Perkembangan Anak Usia Dini Dari 0-6 Tahun. Jurnal Warna, 2(2), 15-28. Ejournal.Iaiig.Ac.Id > Index.Php > Warna > Article > Download

Lusye, M., Lausan, M., Lumi, D. R. N., \& Madalise, H. O. (2020). Peran Orangtua

Dalam Mengajar Sains Anak Usia Dini Pada Masa Pandemi Covid-19. Montessori Jurnal Pendidikan Kristen Anak Usia Dini, 19(2), 1-11.

Muanley, Y. (2009). Pengertian Psikologi Dan Psikologi Pendidikan Agama Kristen.

Http://Psikologikristen.Blogspot.Com/2012/09/Pengertian-Psikologi-Dan-

Psikologi_17.Html

Muanley, Y. (2012). Pengertian Psikologi \& Psikologi Agama Kristen.

Nakamnanu, S. E. (2020). Shamayim : Jurnal Teologi Dan Pendidikan Kristiani Peran Guru Dalam Menerapkan Pendidikan Agama Kristen Untuk Menumbuhkan Iman Kristen Anak Sejak Dini. Jurnal Teologi Dan Pendidikan Kristiani, 1(1), 14-28. Pramana, C. (2020). Pembelajaran Pendidikan Anak Usia Dini (Paud) Dimasa Pandemi Covid-19. Indonesian Journal Of Early Childhood: Jurnal Dunia Anak Usia Dini, 2(2), 116-124. Https://Doi.Org/10.35473/Ijec.V2i2.557

Rahmat, P. S. (2021). Psikologi Pendidikan. Bumi Aksara.

S.T.P. Covid-19. (2020). Gugus Tugas Percepatan Penanganan Covid-19. Gugus Tugas Percepatan Penanganan Covid-19.

Sakerebau, J. (2018). Memahami Peran Psikologi Pendidikan Bagi Pembelajaran. Bia': 
Jurnal Teologi Dan Pendidikan Kristen Kontekstual, 1(1), 96-111.

Https://Doi.Org/10.34307/B.V1i1.22

Shidiq, U., \& Choiri, M. (2019). Metode Penelitian Kualitatif Di Bidang Pendidikan. In Journal Of Chemical Information And Modeling (Vol. 53, Issue 9).

Http://Repository.Iainponorogo.Ac.Id/484/1/Metode Penelitian Kualitatif Di

Bidang Pendidikan.Pdf

Simanjuntak, J. (2016). Psikologi Pendidikan Agama Kristen (5th Ed.). Penerbit Andi.

Slh Sdh, P. (2020). School Curriculum Framework.

Sofia, \& Hartati. (2005). Perkembangan Belajar Pada Anak Usia Dini. Departemen

Pendidikan Nasional.

Supena, A., Nuraeni, S., Rahmitha, Wahyuni, M., Paramita, D., Rasyidi, C., \& Dewey,

S. (2018). Pedoman Penyelenggaraan Pendidikan Anak Usia Dini Inklusif. 30.

Tabi, A. (2020). Problematika Stay At Home Pada Anak Usia Dini Di Tengah Pandemi

Covid 19. Jurnal Golden Age, 4(01), 190-200.

Https://Doi.Org/10.29408/Jga.V4i01.2244

Tafona'o, T. (2019). Kepribadian Guru Kristen Dalam Perspektif 1 Timotius 4:11-16.

Evangelikal: Jurnal Teologi Injili Dan Pembinaan Warga Jemaat, 3(1), 62-81.

Tafonao, T. (2018a). Penerapan Strategi Pengajaran Tuhan Yesus Terhadap Pencapaian

Tujuan Pendidikan Agama Kristen. Prosiding Seminar Nasional "Tata Kelola

Perguruan Tinggi Kristen Di Indonesia," 1(1), 1-6.

Https://Doi.Org/10.31220/Osf.Io/A4b76

Tafonao, T. (2018b). Peran Pendidikan Agama Kristen Dalam Keluarga Terhadap

Perilaku Anak. Edudikara: Jurnal Pendidikan Dan Pembelajaran, Vol 3 (2), 2018

Issn 2541-0261, 3(2), 121-133.

Tas'adi, R. (2019). Hakekat Dan Konsep Dasar Psikologi Pendidikan, Belajar Dan

Pembelajaran. Al-Taujih Bingkai, 5.

Https://Doi.Org/Https://Doi.Org/10.15548/Atj.V5i1.759

Uu No 20 Sistem Pendidikan Nasional. (2003).

Wulandari, H., \& Purwanta, E. (2020). Pencapaian Perkembangan Anak Usia Dini Di

Taman Kanak-Kanak Selama Pembelajaran Daring Di Masa Pandemi Covid-19.

Jurnal Obsesi : Jurnal Pendidikan Anak Usia Dini, 5(1), 452. 
Https://Doi.Org/10.31004/Obsesi.V5i1.626 